\title{
REVITALISASI PASAR TRADISIONAL DALAM MEWUJUDKAN PENGEMBANGAN EKONOMI LOKAL DI KABUPATEN SUMENEP
}

\author{
Rillia Aisyah Haris', Elsya Muzayyana², Irma Irawati $\mathbf{P}^{3}$ \\ 1,2,3Fakultas Ilmu Sosial dan Ilmu Politik, Universitas Wiraraja Sumenep \\ Email: rilliaharis@gmail.com, elsalike00@gmail.com, irma.puspaningrum@gmail.com
}

Article Histori:

Submited: 01/08/2019

Editing: $11 / 09 / 2019$

Publish: 21/10/2019

\begin{abstract}
The various polemics of the traditional market are often the subject of ongoing conversations. Behind all the processes of economic activity that are taking place, the problems that continue to occur today are the slum condition of the market environment, disorderly parking arrangements, and congestion that often occur making the traditional market conditions increasingly out of control. Traditional market revitalization efforts have been carried out. The aim of revitalization which is actually to fix the market becomes more organized, orderly and cleaner for the convenience of the community, but until now it has not been realized. This study uses descriptive qualitative research methods. The focus in this study refers to the role of the government in local economic development through revitalization of traditional markets including the role of the coordinator and the role of the facilitator. The results of the study indicate that the local government has acted as a coordinator and facilitator in revitalizing traditional markets but has not been able to carry out optimally. One reason is the absence of a clear and specific legal umbrella governing traditional market revitalization. Some recommendations that can be offered are: 1) The Sumenep Regency Government needs to coordinate with all stakeholders involved to identify problems while finding appropriate solutions to problems in traditional market revitalization; 2) The local government of Sumenep Regency needs to establish specific policies governing the revitalization of traditional markets so that the objective of market revitalization can be achieved optimally; 3) Carry out monitoring and evaluation of the revitalization program.
\end{abstract}

Keyword: Traditional Market Revitalization, Local Economic Development, Role of Government

\section{PENDAHULUAN}

Pembangunan ekonomi masih menjadi salah satu sasaran utama yang terus diupayakan oleh setiap daerah dalam mencapai kemakmuran rakyat. Pembangunan ekonomi tidak hanya berkaitan dengan pertumbuhan ekonomi, namun juga terjadinya perubahan di 
berbagai aspek kegiatan ekonomi seperti peningkatan dalam infrastruktur, peningkatan pendapatan dan kemakmuran masyarakat (Sukirno, 2010:10). Kondisi demikian menjadi tantangan tersendiri bagi pemerintah daerah dalam melaksanakan peranannya.

Selaras dengan upaya pembangunan ekonomi yang sedang gencar dilakukan diberbagai daerah, saat ini pemerintah daerah dituntut untuk ikut serta berperan aktif dalam mensukseskan pembangunan nasional salah satunya melalui Program Revitalisasi Pasar Tradisional atau yang lebih dikenal dengan Pasar Rakyat dengan tujuan utama yaitu terwujudnya perekonomian rakyat melalui adanya peningkatan pendapatan para pedagang serta pelaku-pelaku ekonomi yang ada di masyarakat. Pemerintah daerah bertugas untuk dapat mengendalikan program tersebut melalui pemetaan, pemeliharaan dan pengelolaan serta pemberdayaan pasar. (Mensukseskan Program Revitalisasi Pasar Tradisional. Dalam situs http:// presidenri.go.id. Diakses 20 Oktober 2017).

Sejalan dengan hal tersebut, revitalisasi pasar tradisional telah menjadi salah satu program unggulan pemerintah daerah Kabupaten Sumenep sebagai agenda kegiatan yang urgent untuk dilakukan. Program revitalisasi sebagai upaya perbaikan terhadap keberadaan pasar tradisional menjadi langkah yang ditempuh untuk dapat menyelesaikan segenap permasalahan yang terjadi. Adapun maksud dari pelaksanaan program tersebut yaitu untuk meningkatkan kenyamanan dan pelayanan kepada masyarakat, menghilangkan kesan kumuh pasar tradisional, serta rehabilitasi sarana dan prasarana (Program Kerja 99 hari, Bupati dan Wakil Bupati Sumenep Terpilih. Dalam situs http:// newsmadura.com. Diakses tanggal 7 September 2017).

Berdasarkan perkembangan yang terjadi hingga saat ini, ternyata proses revitalisasi pasar tradisional Kabupaten Sumenep belum mampu menyelesaikan berbagai permasalahan yang ada di dalam pasar itu sendiri. Tujuan revitalisasi yang sejatinya untuk membenahi pasar menjadi lebih teratur, tertib dan bersih demi kenyamanan masyarakat, namun hingga saat ini tidak kunjung terealisasi. Berbagai polemik pasar tradisional kerap menjadi bahan perbincangan yang tidak kunjung usai.

Realita menunjukkan sejumlah permasalahan yang masih terlihat salah satunya yakni pada pasar Anom Baru sebagai pasar tradisional terbesar di Kabupaten Sumenep. Dibalik semua proses kegiatan perekonomian yang berlangsung, permasalahan yang terus terjadi hingga saat ini yaitu kondisi lingkungan pasar yang kumuh, penataan parkir yang tidak tertib, serta kemacetan yang sering kali terjadi menjadikan kondisi pasar tradisional tersebut semakin tidak terkendali. Penataan pasar yang masih terkesan berantakan, hal tersebut mendapat banyak sorotan dari berbagai kalangan mulai dari para pedagang hingga anggota DPRD setempat. (Alif, Fathol. Pasar Anom Baru Masih Semrawut, Komisi II segera panggil Disperindag. Dalam situs $\begin{array}{lll}\text { www.koranmadura.com. } & \text { Diakses } 7\end{array}$ September 2017 ).

Berdasarkan beberapa hal yang telah dipaparkan, maka penulis tertarik untuk membahas dan menganalisa mengenai Revitalisasi Pasar Tradisional dalam Mewujudkan Pengembangan Ekonomi Lokal di Kabupaten Sumenep.

Dalam pembangunan ekonomi daerah pemerintah memilki peranan yang sangat menentukan terhadap berjalannya sebuah 
proses pembangunan. Adapun peran pemerintah dapat mencakup peran-peran wirausaha (enterpreneur), koordinator, fasilitator, dan stimulator (Blakely, dalam Mudrajat 2011:113). Pemerintah daerah sebagai koordinator bertindak untuk menetapkan kebijakan atau menentukan strategi-strategi bagi pembangunan daerahnya. Dalam melaksanakan perannya sebagai koordinator dalam pembangunan ekonomi, pemerintah dapat melibatkan kelompok-kelompok masyarakat, ataupun berkejasama dengan lembaga pemerintah, dan badan usaha untuk menyusun tujuan, maupun strategi ekonomi. Secara normatif koordinasi diartikan sebagai kewenangan untuk menggerakkan, menyerasikan, dan menyeimbangkan kegiatan-kegiatan yang spesifik atau berbeda-beda agar semuanya terarah pada satu tujuan. Menurut Terry dalam Arifin (2012:95), koordinasi merupakan suatu usaha yang singkron dan teratur untuk menyediakan jumlah dan waktu yang tepat, dan mengarahkan pelaksana untuk menghasilkan suatu tindakan yang seragam dan harmonis pada sasaran yang telah di tentukan.

Pemerintah daerah sebagai fasilitator dapat mempercepat pembangunan melalui perbaikan lingkungan perilaku daerahnya. Peran ini dapat meliputi pengefisienan proses pembangunan, perbaikan prosedur, dan penetapan peraturan. Fasilitator diartikan sebagai elemen yang mendampingi, memberi semangat, pengetahuan, bantuan, saran dalam suatu kelompok dalam memecahkan masalah sehingga kelompok dapat lebih maju (Nn, 2007:1). Filosofi dari fasilitator adalah adanya suatu kelompok yang memiliki tujuan, rencana, gagasan, program, sarana dalam melaksanakan kegiatan dalam memecahkan masalah yang dihadapi secara bersama-sama.

Menurut Arif (2012) peran pemerintah sebagai fasilitator adalah menciptakan kondisi yang kondusif bagi pelaksanaan pembangunan, menjembatani kepentingan berbagai pihak dalam mengoptimalkan pembangunan daerah. Sebagai fasilitator pemerintah berusaha untuk menciptakan atau memfasilitasi suasana yang tertib, aman dan nyaman termasuk memfasilitasi tersedianya sarana dan prasarana pembangunan seperti pendampingan dan pendanaan (Jurnal Ilmu Pemerintahan tahun 2014). Dalam melaksanakan peranannya, pemerintah sebagai fasilitator juga harus mampu menyediakan informasiinformasi beserta pendukungnya, membantu mengakses potensi, menengahi permaslahan yang terjadi serta menjadi perangsang bagi masyarakat dalam menggali kapasitas dirinya (Jhohani, 2007 dalam junal Ilmu Pemerintahan). Pemerintah daerah dapat menstimulasi penciptaan dan pengembangan usaha melalui tindakan-tindakan khusus yang akan mempengaruhi perusahaanperusahaan untuk masuk ke daerah.

Revitalisasi menurut Danisworo dalam Jurnal Manajemen dan Bisnis, adalah upaya untuk memvitalkan kembali suatu kawasan yang dulu pernah vital, akan tetapi mengalami kemunduran atau degradasi. Revitalisasi pasar merupakan usaha untuk memvitalkan kembali fungsi pasar tradisional yang semakin terkikis karena persaingan oleh pasar modern. Menurut Paskarina (2010) dalam jurnal adminisrasi publik, dasar pertimbangan melakukan kerjasama merevitalisasi pasar tradisional antara lain berubahnya pandangan pasar yang tidak hanya sebagai pusat interaksi ekonomi, namun juga sebagai ruang publik yang difokuskan pada upaya memperbaiki jalur distribusi komoditas yang diperjualbelikan. Fungsi pembangunan pasar juga diharapkan tidak hanya mencari keuntungan finansial dan merupakan langkah untuk meningkatkan perekonomian perdagangan kecil serta 
perlu melibatkan pengembang untuk dikelola secara kreatif. Revitalisasi pasar erat kaitannya dengan good governance dan pembangunan daerah, yang mana berdasarkan dari manajemen dan tatakelola pemerintahan daerah setempat bertujuan untuk memperbaiki dan meningkatkan kesejahteraan masyarakat. Revitalisasi pasar tradisional dalam kaitan ini dapat dilihat dari fungsi pasar sendiri sebagai penopang perekonomian yang langsung berhubungan dengan tingkat pendapatan dan kesejahteraan masyarakat (Alfianita, Jurnal Administrasi Publik Vol. 3, No. 5).

\section{METODE PENELITIAN}

Metode penelitian yang dipakai dalam penelitian ini ialah penelitian kualitatif. Fokus dalam penelitian ini mengacu pada teori Blakely, dalam Mudrajat (2011:113) yaitu tentang peran pemerintah dalam pembangunan ekonomi lokal yang meliputi peran koordinator dan peran fasilitator. Lokus penelitian ini pada Dinas Perindustrian dan perdagangan Kabupaten Sumenep. Dalam penelitian ini terdapat lima sampel pasar tradisional Kabupaten Sumenep yang telah dilakukan revitalisasi di tahun 2017 diantaranya pasar Batangbatang, pasar Kebundadap, pasar Ambunten, Pasar Gapura dan pasar Bringin.

Sumber data dalam penelitian ini diperoleh dari data primer dan data sekunder. Pengumpulan data dilakukan melalui wawancara, observasi dan dokumentasi. Instrumen penelitian meliputi peneliti sendiri, pedoman wawancara dan alat penunjang lainnya dalam melakukan dokumentasi dilapangan. Teknik anaisa data menggunakan model Miles and Huberman dalam Sugiyono (2016:244) yang terdiri dari data reductions, data display dan conclutions.

\section{HASIL DAN PEMBAHASAN}

Pembangunan ekonomi lokal merupakan proses kegiatan yang dilaksanakan pemerintah daerah dan masyarakatnya dalam mengelola segala sumberdaya yang ada untuk kepentingan dan kesejahteraan rakyatnya. Dalam pelaksanaan otonomi daerah diperlukan arahan yang benar dan pemberdayaan terhadap segala potensi untuk menjawab tatantangan era globalisasi. Pelaksanaan pemberdayaan daerah perlu diupayakan untuk mendorong upaya pemanfaatan dan pembangunan yang terbatas untuk meningkatkan ketahanan dan daya saing ekonomi daerah melalui peningkatan kapasitas pemerintah daerah dan masyarakat secara efektif untuk meningkatkan ekonomi lokal, meningkatkan kesempatan kerja, dan pendapatan masyarakat, dan pada gilirannya meningkatkan kemampuan ekonomi dan pendapatan daerah (Rahardjo, $2011: 46)$.

Pemerintah daerah Kabupaten Sumenep telah melakukan beberapa upaya pembangunan perekonomian lokal salah satunya dengan dilaksanakannya program revitalisasi pasar. Namun, berdasarkan sejumlah realita yang ada menunjukkan belum optimalnya pelaksanaan revitalisasi pasar yang terjadi di daerah Kabupaten Sumenep. Pada dasarnya upaya perbaikan pasar tradisional bukan hanya menitikberatkan pada unsur fisik semata, namun lebih daripada itu perbaikan aspek manajemen menjadi sebuah keharusan yang perlu untuk dilakukan. Perbaikan manajemen pengelolaan pasar akan menjadikan pasar tradisional lebih terarah, dalam hal ini kaitannya pula dengan keberadaan pedagang, tata cara, maupun standart operasional prosedur pelayanan pasar. Oleh karenanya perbaikan unsur nonfisik juga menjadi elemen penting bagi 
terwujudnya pembangunan pasar yang berkelanjutan.

Upaya revitalisasi menjadi kesempatan terbaik yang seharusnya dapat dilaksanakan seoptimal mungkin oleh pemerintah daerah dalam memperbaiki kondisi pasar tradisional. Profesionalitas pengelola pasar menjadi bagian yang turut berpengaruh terhadap penyelenggaraan program revitalisasi dalam mencapai sasaran yang diinginkan. Tidak dapat dipungkiri bahwasanya perbaikan yang dilakukan menjadi salah satu alasan daerah untuk mencapai suatu pembangunan ekonomi masyarakat, karena sejatinya keberadaan pasar tradisional merupakan pilar perekonomian rakyat.

Keberhasilan program dan pencapaian tujuan yang diharapkan tidak terlepas dari peran pemerintah untuk mengatur jalannya revitalisasi pasar, khususnya bagi pemerintah Kabupaten Sumenep yang turut melaksanakan program revitalisasi pasar tradisional sehingga upaya tersebut mampu menyelesaikan berbagai bentuk permasalahan yang selama ini terjadi, dan menjadikan pasar tradisional berdaya saing dengan menyedot perhatian masyarakat, serta dapat meningkatkan keuntungan dan menjamin kelangsungan dari pasar itu sendiri demi mewujudkan pembangunan ekonomi masyarakat.

Berdasarkan data Dinas Perindustrian dan Perdagangan Kabupaten Sumenep jumlah pasar tradisional yang ada di Kabupaten Sumenep yaitu sebanyak 36 pasar yang terbagi menjadi pasar kota dan pasar kecamatan.

Tabel 1. Daftar Pasar Tradisional Kabupaten Sumenep

\begin{tabular}{|c|l|l|}
\hline No & PASAR KOTA & $\begin{array}{l}\text { PASAR } \\
\text { KECAMATAN }\end{array}$ \\
\hline 1 & Anom Baru & Lenteng \\
\hline 2 & Bangkal Polowijo & Rubaru \\
\hline 3 & Shoping Center & $\begin{array}{l}\text { Nyappar } \\
\text { Dasuk }\end{array}$ \\
\hline
\end{tabular}

\begin{tabular}{|c|l|l|}
\hline No & PASAR KOTA & $\begin{array}{c}\text { PASAR } \\
\text { KECAMATAN }\end{array}$ \\
\hline 4 & 17 Agustus & Ganding \\
\hline 5 & Manding & Gapura \\
\hline 6 & Marengan & Batang-batang \\
\hline 7 & Pabrik & Legung Timur \\
\hline 8 & Tambangan & Banasare \\
\hline 9 & Talango & Prenduan \\
\hline 10 & Pinggirpapas & Candi \\
\hline 11 & & Kolpo \\
\hline 12 & & Bluto \\
\hline 13 & & Dungkek \\
\hline 14 & & Pasongsongan \\
\hline 15 & & Ambunten \\
\hline 16 & & Batuputih \\
\hline 17 & & Keles \\
\hline 18 & & Basoka \\
\hline 19 & & Bintaro \\
\hline 20 & & Beringin \\
\hline 21 & & Lenteng Barat \\
\hline 22 & & Guluk-guluk \\
\hline 23 & & Kebundadap \\
\hline 24 & & Bicabbi \\
\hline 25 & & Beragung \\
\hline 26 & & $\begin{array}{l}\text { Pakandangan } \\
\text { Sangra }\end{array}$ \\
\hline
\end{tabular}

Sumber : Data Dinas Perindustrian dan Perdagangan Kabupaten Sumenep.

Dalam pelaksanaan kegiatan revitalisasi pasar tradisional untuk pembangunan ekonomi masyarakat, pemerintah memiliki peran sebagai koordinator. Peran koordinator pemerintah dalam pembangunan ekonomi itu sendiri ialah untuk menyusun tujuan maupun strategi ekonomi dengan melibatkan lembaga pemerintah lainnya, badan usaha maupun kelompok-kelompok masyarakat (Mudrajat, 2004:113). Berdasarkan hasil penelitian dapat diketahui bahwa koordinasi terjalin baik di lingkup internal maupun eksternal. Pelaksanaan revitalisasi dilakukan bersama-sama antara Disperindag, UPT, penjab pasar maupun 
para pelaku ekonomi untuk menerapkan berbagai stategi ekonomi yang telah disiapkan meliputi kegiatan zonasi maupun strategi dalam merangsang pertumbuhan aktifitas ekonomi di pasar itu sendiri.

Kegiatan zonasi dimaksudkan untuk merubah kondisi pasar sehingga mampu menjadikan pasar lebih tertib dan bisa memberikan kenyamanan bagi para pelaku ekonomi di dalamnya. Adapun upaya yang dilakukan oleh Disperindag dalam hal zonasi telah dilaksanakan sesuai ketentuan yang ada, yaitu berdasarkan pada ketentuan Standart Nasional Indonesia (SNI 8152, 2015).

Pasar Rakyat dalam melakukan perbaikan terhadap manajemen pasar tradisional, pelaksanaan zonasi tersebut harus memenuhi syarat diantaranya :

a. Dikelompokkan secara terpisah untuk bahan pangan basah, bahan paangan kering, siap saji, non pangan

b. Memiliki jalur yang mudah diakses untuk seluruh konsumen dan tidak menimbulkan penumpukan orang pada satu lokasi tertentu

c. Terdapat papan nama yang menunjukkan keterangan lokasi zonasi

Selain itu, kegiatan koordinasi juga dilakukan untuk dapat melaksanakan strategi ekonomi yang kedua yakni dalam menghidupkan pasar tradisional yang sudah hampir mati akibat tidak adanya aktifitas ekonomi. Sebagaimana hasil penelitian yang telah dipaparkan bahwasannya pasar Batang-batang merupakan pasar tradisional yang hampir mati akibat tidak adanya pedagang. Oleh sebab itulah tempat tersebut menjadi salah satu sasaran revitalisasi yang dilakukan Disperindag di tahun 2017. Salah satu upaya yang diusahakan untuk dapat mengaktifkan pasar Batang-batang kembali yakni dengan cara mengundang pedagang dari daerah lain untuk dapat meramaikan pasar demi merangsang aktifitas ekonomi di pasar tersebut dengan aturan tertentu yang dibuat berdasarkan kesepakatan bersama antara pemerintah daerah dengan para pelaku ekonomi dengan memberlakukan hari pasaran yang terjadwal dan disosialisasikan kepada para pedagang. Pelaksanaan strategi ini juga merupakan jalan untuk dapat mengaktifkan kembali pedagang-pedagang khususnya daerah Batang-batang untuk kembali melakukan aktifitas ekonomi sehinga dapat memberikan manfaat bagi pedagang daerah setempat. Berdasarkan hasil penelitian yang dilakukan dapat diketahui kegiatan ekonomi masyarakat khususnya di Batang-batang telah aktif dan pulih kembali sejak dilakukannya revitalisasi pasar tradisional Batang-batang.

Dalam pelaksanaan strategi ekonomi yang kedua,sekalipun hal tersebut sudah dapat terlaksana dengan baik akan tetapi masih dibutuhkan koordinasi lebih lanjut untuk benar-benar dapat mencapai sasaran perencanaan yang telah ditetapkan sebelumnya. Arah dari penerapan stategi ini sebenarnya ialah bagaimana pedagang tersebut dapat berjualan di satu waktu pada hari pasaran sehingga hal itu membuat pasar Batang-batang menjadi lebih ramai. Namun demikin hal itu masih terkendala sehingga diperlukan koordinasi dan komunikasi lebih lanjut untuk menentukan hari pasaran. Kondisi demikian mengharuskan pemerintah dan para pelaku ekonomi untuk terus berkoordinasi dalam mencari solusi atas setiap kendala yang terjadi sehingga tercipta kesepakatan bersama khususnya dalam menentukan jadwal hari pasaran, karena hal ini dimaksudkan untuk dapat menghidupkan pasar Batang-batang dengan jumlah pedagang yang semakin banyak yang pada akhirnya hal tersebut dapat memberikan dampak yang baik untuk perekonomian masyarakat. 
Dalam menerapkan berbagai strategi ekonomi tersebut, koordinasi sangat penting untuk terus dilakukan mengingat hal tersebut merupakan jalan untuk meyelasaraskan tindakan dalam rangka pembangunan ekonomi masyarakat. Sebagaimana yang disampaikkan olehArifin (2012, 94) bahwasannya koordinansi merupakan kewenangan untuk dapat menggerakkan, menyerasikan, dan menyeimbangkan kegiatan-kegiatan yang spesifik atau berbeda-beda agar semuanya terarah pada satu tujuan. Adapun menurut George Terry dalam Arifin (2012, 95), koordinasii merupakan suatu usaha yang singkron dan teratur, dan mengarahkan pelaksana untuk menghasilkan suatu tindakan yang seragam dan harmonis pada sasaran yang telah ditentukan.

Koordinasi yang terus menerus antara pemerintah dan pedagang akan memberikan kemudahan bagi pelaksanaan strategi yang telah ditetapkannya. Dalam hal ini komunikasi harus terus dibangun guna menyatukan tindakan demi kepentingan bersama. Hal demikian sebagaimana yang sampaikan oleh Arifin (2012 : 107) bahwasannya koordinasi bukan hanya bekerjasama, melainkan juga integrasi dan singkronisasi yang mengharuskan penyelarasan unsur-unsur jumlah dan penentu waktu kegiatan disamping penyesuaian perencana, dan keharusan adanya komunikasi yang teratur diantara semua pelaku yang bersangkutan demi mengindahkan ketentuan yang berlaku sebagai suatu peraturan pelaksanaan. Demikian pula menurut Handayaningrat (2012:96), dimana koordinasi dan komunikasi merupakan sesuatu hal yang tidak dapat dipisahkan dan merupakan proses yang berkesinambungan (Continues Procces), dimana kesatuan tindakan menjadi inti dari sebuah koordinasi. Pemerintah bertugas untuk mengatur usaha/tindakan-tindakan yang akan dilakukan sehingga diperoleh adanya keserasian dalam kerjasama yang tercipta.

Selama pelaksanaan koordinasi, tidak dapat dipungkiri masih terdapat kendala yang dirasakan dalam penerapan upaya strategi ekonomi yang dilakukannya. Masih ditemukan beberapa pedagang yang tidak menempati lokasi yang telah disediakan oleh pemerintah. Dalam mengatasi hal ini maka pemerintah perlu menyusun aturan dan sanksi tegas sekaligus melakukan pendekatan-pendekatan berbasis kearifan lokal. Sehingga tujuan koordinasi mampu tercapai dengan baik dan hubungan antara pemerintah dengan para pelaku ekonomi dipasar tetap terjalin harmonis.

Peran pemerintah sebagai fasilitator menyatakan bahwa pemerintah dalam hal ini bertugas untuk dapat memenuhi segala kebutuhan masyarakatnya dalam menunjang segala aktifitas ekonominya. Tidak hanya kebutuhan berupa fisik, namun pula segala kebutuhan non fisik untuk dapat menjembatani berbagai kepentingan yang dibutuhkannya. Menurut Arif (2012) peran pemerintah sebagai fasilitator adalah berusaha untuk menciptakan atau memfasilitasi suasana yang tertib, aman dan nyaman termasuk memfasilitasi tersedianya sarana dan prasarana pembangunan seperti pendampingan dan pendanaan.

Dalam pelaksanaan revitalisasi pasar tradisional, hal pertama kali yang dilakukan oleh Disperindag ialah perbaikan dan pemenuhan kebutuhan akan fasilitas fisik berupa revitalisasi bangunan yang sudah ada ataupun penambahan bangunan baru bagi para pelaku ekonomi. Hal tersebut sebagaimana menurut Permendagri Nomor 37 Tahun 2017 pasal 18 bahwasannya revitalisasi sarana perdagangan meliputi pembangunan baru atau revitalisasi yang sudah ada.

Beberapa bentuk fasilitasi dalam revitalisasi pasar rakyat yang telah 
dilakukan oleh Disperindag berupa pembangunan meliputi bangunan utama yaitu kios/toko, los (Dokumen Disperindag tentang Petunjuk Teknis DAK Bidang Pasar). Kios/toko merupakan ruang dagang yang mempunyai dinding terpisah, sedangkan los merupakan ruang dagang yang bersifat tetap dan terbuka serta dapat dilengkapi dengan meja (SNI Pasar Rakyat, 2015). Adapaun fasilitasi terhadap penambahan sarana pendukung lainnya berupa kamar mandi dan musolla.

Berdasarkan hasil penelitian pada tahun 2017 terdapat lima pasar kecamatan yang telah dilakukan revitalisasi dengan perbaikan maupun pembangunan sarana fisik sebagaimana tabel 2 berikut ini:

Tabel 2. Revitalisasi Pasar Kabupaten Sumenep Tahun 2017

\begin{tabular}{|c|l|c|c|c|}
\hline No & Nama Pasar & $\begin{array}{c}\text { Kios/ } \\
\text { Toko }\end{array}$ & Los & $\begin{array}{c}\text { Sarana } \\
\text { Lainny } \\
\text { a }\end{array}$ \\
\hline 1. & Kebundadap & 3 & 1 & $\begin{array}{l}2 \text { kamar } \\
\text { mandi }\end{array}$ \\
\hline 2. & Gapura & 19 & 1 & $\begin{array}{l}3 \text { kamar } \\
\text { mandi }\end{array}$ \\
\hline 3. & $\begin{array}{l}\text { Batang- } \\
\text { batang }\end{array}$ & 8 & 2 & - \\
\hline 4. & Bringin & - & 3 & $\begin{array}{l}1 \\
\text { kamar } \\
\text { mandi }\end{array}$ \\
\hline 5. & Ambunten & 17 & - & $\begin{array}{l}1 \text { kamar } \\
\text { mandi } \\
\text { dan } 1 \\
\text { musoll } \\
\text { a }\end{array}$ \\
\hline
\end{tabular}

Sumber : Data diolah

Pemberian fasilitas fisik oleh pemerintah tersebut diharapkan dapat menunjang aktifitas yang terjadi di pasar melalui perbaikan dan penambahan lokasi dagang yang telah disediakan. Beberapa lokasi pedagang saat ini dirasa sudah lebih baik apabila dibandingkan dengan tempat sebelumnya. Dalam perannya sebagai fasilitator, sebagaimana pendapat Arif
(2012), pemerintah berusaha untuk memfasilitasi tersedianya sarana dan prasarana pembangunan seperti pendampingan dan pendanaan.

Berdasarkan penelitian yang telah dilakukan dapat ketahui bahwa kegiatan perbaikan fisik yang dilakukan telah mampu memberikan kenyamanan bagi para pelaku ekonomi. Adapun manfaaat lainnya yang dapat dirasakan ialah tumbuhnya pedagang-pedagang baru akibat terpenuhinya ruang yang lebih luas bagi mereka untuk berwirausaha. Banyak pula diantara mereka yang dulunya pernah menghentikan aktifitas ekonominya, kini mulai beroperasi kembali untuk menjajakan dagangannya. Kegiatan menghidupkan kembali aktifitas ekonomi masyarakat tersebut seperti yang terjadi di Kecamatan Batang-batang, pada akhirnya dapat menarik perhatian para konsumen dan menambah pendapatan bagi para pelaku ekonomi di pasar tersebut.

Berdasarkan data dilapangan maka pembenahan fisik yang diberikan oleh pemerintah berkaitan pula dengan pembangunan ekonomi yang tidak hanya dilihat dari kenaikan pendapatan, namun juga berbagai aspek kegiatan ekonomi seperti peningkatan dalam infrastruktur dan kemakmuran masyarakat (Sukirno, 2010). Tingkat kemakmuran masyarakat dalam pembangunan ekonomi sebagaimana yang disampaikan oleh Raharjo (2013:99) bahwasannya pendapatan perkapita tidak dapat dijadikan sebagai indikator kesejahteraan, karena tidak dapat dikatakan sejahtera apabila masih merasakan kesulitan dalam sebuah pelayanan. Dalam pelayanan publik, kemudahan (easyness) diartikan sebagai tersedianya fasilitas pelayanan (ekonomi dan sosial) sehingga masyarakat dapat memenuhi berbagai kebutuhan hidupnya. Tersedianya fasilitas pelayanan mampu memberikan kemudahan terhadap 
pemenuhan berbagai kebutuhan masyarakat, sehingga masyarakat merasa berkecukupan atau sejahtera karena segala yang dibutuhkan dapat diperoleh dengan mudah (Poernomosidi dalam Raharjo, 2013: 99-100). Dalam hal ini pemerintah daerah Kabupaten Sumenep melalui Disperindag memberikan layanan dengan merevitalisasi pasar tradisional untuk menggerakkan dan meningkatkan perekonomian masyarakat.

Melalui tersedianya sarana fisik tersebut maka setiap pedagang telah mendapatkan kenyamanan dan kemudahan untuk malakukan aktifitas ekonominya. Banyak diantara meraka yang sudah memiliki kios/ lokasi untuk berjualan akibat penambahan sarana fisik yang diberikan oleh pemerintah dalam revitalisasi pasar Kabupaten Sumenep. Para pedagang yang sebelumnya tidak memiliki tempat kini telah menempati lokasi masing-masing sesuai aturan dan penataaan yang disediakan. Dalam pemberian fasilitas ini didasarkan bagi kepentingan para pelaku ekonomi yaitu para pedagang. Pemerintah telah menyediakan ruang agar dapat dimanfatkan semaksimal mungkin sehingga mampu memberikan dampak baik bagi peningkatan pendapatan masyarakat.

Langkah pemerintah sebagai fasilitator tidak cukup pada pemberian sarana fisik semata, namun lebih dari pada itu upaya untuk menjembati kepentingan, pembenahan perilaku dan pelaksanaan aturan yang ada di dalamnya juga harus diperhatikan untuk dapat mengefisienkan suatu pencapaian tujuan khususnya dalam perbaikan lingkungan pasar tradisional. Dalam hal ini maka pemerintah selaku fasilitator harus mampu menyediakan informasi-informasi beserta pendukungnya, membantu mengakses potensi, serta menjadi perangsang bagi masyarakat dalam menggali kapasitas dirinya (Jhohani, 2007 dalam jurnal Ilmu Pemerintahan). Pendapat lain mengenai fungsi fasilitator sebagai pihak yang menjembatani kepentingan masyarakat yakni menurut Nurman (2015:87) filosofi fasilitator adalah adanya suatu kelompok yang memiliki tujuan, rencana, gagasan, program saranaa dalam melaksanakan kegiatan serta memecahkan masalah yang dihadapai secara bersamasama. Sejalan dengan pernyataan tersbut maka Disperindag bersama dengan UPT dan Penjab pasar senantiasa melakukan kontrol terhadap situasi dan perkembangan pasar tradisional. Kegiatan kontrol tersebut dilaksanakan setiap hari pasaran tertentu sesuai jadwal masing-masing pasar tradisional yang ada di Kabupaten Sumenep.

UPT dan Penjab pasar secara rutin melakukan kroscek terhadap masingmasing pasar yang ada, yang mana selama kegiatan kontrol dilaksanakan petugas tidak hanya melakukan penarikan karcis, akan tetapi mereka juga bertugas untuk memahami segala permasalahan yang terjadi di pasar. Melihat pada kondisi yang sebenarnya bahwasannya masih terdapat beberapa pelaku ekonomi yang sulit di atur, dimana hal itu dapat menyebabkan keadaan pasar yang tidak kondusif. Oleh sebab itu maka keadaan tersebut juga menjadi tanggung jawab pemerintah untuk dapt memperbaiki lingkungan perilaku tersebut. Dalam hal ini pula petugas berusaha untuk melihat perkembangan dan situasi pasar yang nantinya akan menjadi masukan sebagai bahan pertimbangan bagi perbaikan pasar kedepannya. Hakikat keberadaan fasilitator menurut Nunun (2007:11) bahwasanya fasilitator merupakan elemen yang mendampingi, memberi semangat, pegetahuan, bantuan, saran dalam suatu kelompok dalam memecahkan masalah sehingga kelompok dapat lebih maju. Oleh karenanya fungsi fasilitator menjadi penting sehingga pemerintah mampu menjadi jalan bagi tercapainya segala keinginan masyarakat melalui perbaikan lingkungan 
pasar dalam rangka pembangunan ekonomi.

Disperindag bersama UPT Pasar berupaya memberikan pembinaan terhadap pedagang untuk memperbaiki lingkungan perilaku dalam rangka revitalisasi manajemen pasar, sehingga setiap pedagang mampu mengetahui segala hak dan kewajiban yang harus dilaksanakan. Disamping itu pula profesionalisme pemerintah dalam menegakkan peraturan yang ada harus benar-benar dilaksanakan demi mencapai perbaikan perilaku masingmasing pelaku ekonomi sekaligus perbaikan manajemen pengelolaan pasar rakyat. Seperti halnya yang terjadi pada permasalahan toko/kios yang sudah berpemilik akan tetapi tidak beroperasi dan melebihi batas waktu sebagaimana yang telah diterapkan, maka hal ini harus segera ditindak. Apabila hal demikian tetap dibiarkan tidak hanya berdampak pada lemahnya aktifitas pasar namun juga menutup kesempatan bagi pedagang lain yang ingin menempati lokasi tersebut.

Sebagaimana termaktub dalam tujuan revitalisasi pasar, pemerintah dalam hal ini sudah seharusya dapat melakukan pembinaan yang lebih mendalam terkait hak-hak dan kewajiban setiap pelaku ekonomi sehingga mereka dapat benarbenar memahami tugas dan tanggungjawabnya dalam rangka mencapai tujuan berasama yakni terciptanya pasar yang aman, nyaman tertib dan mampu meningkatkan pendapatan bagi masyarakatnya. Ketegasan pemerintah juga sangat diperlukan dalam menegakkan aturan yang ada sehingga tercipta keteraturan dalam pelaksanaan seluruh aktifitas ekonomi masyarakat.

Keberadaan pemerintah sebagai fasilitator terutama dalam memperbaiki lingkungan pasar untuk pembangunan ekonomi masyarakat bukanlah hal yang mudah untuk dijalankan. Perbaikan lingkungan perilaku masyarakat juga menjadi tantangan yang harus dihadapi bersama antara pemerintah dan para pelaku ekonomi.

Program revitalisasi sebagai upaya perbaikan yang dilakukan terhadap keberlangsungan pasar tradisional pada dasarnya harus memiliki empat prinsip yang harus diperhatikan dalam pelaksanaannya meliputi:

a. Revitalisasi Fisik, meliputi perbaikan dan peningkatan kualitas dan kondisi fisik bangunan, tata hijau, sistem penghubung, sistem tanda/reklame dan ruang terbuka kawasan.

b. Revitalisasi manajemen, yaitu pasar harus mampu membangun manajemen pengelolaan pasar yang mengatur secara jelas aspek-aspek seperti hak dan kewajiban pedagang, tata cara penempatan, pembiayaan, fasilitasfasilitas yang harus tersedia di pasar, standar operasional prosedur pelayanan pasar

c. Revitalisasi ekonomi, yakni perbaikan fisik kawasan yang bersifat jangka pendek untuk mengakomodasi kegiatan ekonomi informal dan formal (local economic development)

d. Revitalisasi sosial, menciptakan lingkungan yang menarik dan berdampak positif serta dapat meningkatkan dinamika dan kehidupan sosial masyarakat/warga (public realms). (Mensukseskan Program Revitalisasi Pasar Tradisional. Dalam situs http://presidenri.go.id. Diakses 20 Oktober 2017).

Prinsip-prinsip tersebut telah terlaksana namun belum optimal, salah satu alasan yang mendasari adalah belum adanya peraturan daerah yang khusus mengatur tentang revitalisasi pasar. Program revitalisasi pasar ini hanya disandarkan 
pada peraturan daerah tentang penataan pasar tradisional dan pasar modern saja yaitu Peraturan Daerah Nomor 5 Tahun 2013 tentang Perlindungan, Pemberdayaan Pasar Tradisional Dan Penataan Pasar Modern. Padahal dana yang disiapkan pemerintah daerah kabupaten sumenep tidak sedikit. Tahun ini menganggarkan 5,4 miliar untuk revitalisasi.

Untuk itu perlu dilakukan beberapa kajian untuk memformulasikan kebijakan revitalisasi pasar tradisional. Formulasi kebijakan tersebut meliputi analisa sosial ekonomi, analisa sosio demografi, analisa potensi lokal dengan melibatkan semua elemen yang berkepentingan di dalamnya baik itu pihak pemerintah daerah, swasta dan masyarakat. Masyarakat yang dimaksud disini bukan hanya masyarakat sebagai konsumen tetapi masyarakat yang bertindak dan berperan sebagai pelaku ekonomi yaitu para pedagang di pasar. Sebagaimana kita ketahui para pedagang pasar tersebut telah dinaungi dalam sebuah paguyupan pedagang pasar. Hal ini penting karena mereka yang terlibat langsung dan merupakan pelaku ekonomi di pasar tradisional. Untuk itu penting sekali melakukan focus grup discussion ataupun sounding antara pemerintah, swasta dan masyarakat.

Dengan metode FGD dan sounding ini diharapkan mampu menyerap aspirasi semua pihak agar nantinya dapat merumuskan kebijakan revitalisasi pasar secara efektif dan efisien. Kebijakan tersebut mampu menjadi solusi dari banyaknya masalah dan hambatan dalam upaya revitalisasi pasar tradisional sebagai wujud peningkatan perekonomian masyarakat lokal.

\section{PENUTUP}

Hasil penelitian menunjukkan bahwa pemerintah daerah Kabupaten Sumenep telah berperan sebagai koordinator dan fasilitator dalam merevitalisasi pasar tradisional namun belum mampu terlaksana secara optimal yang disebabkan belum adanya payung hukum yang jelas dari kebijakan pembangunan ekonomi lokal melalui revitalisasi pasar tradisional.

Adapun rekomendasi yang dapat ditawarkan yaitu:

1. Pemerintah Kabupaten Sumenep perlu berkoordinasi dengan seluruh stakeholder yang terlibat untuk identifikasi masalah sekaligus mencari solusi yang tepat terhadap permasalahan dalam revitalisasi pasar tradisional.

2. Pemerintah Kabupaten Sumenep perlu melakukan focus grup discussion ataupun sounding antara stakeholder yang terlibat baik pemerintah, swasta dan masyarakat.

3. Pemerintah daerah Kabupaten Sumenep perlu menetapkan kebijakan khusus yang mengatur tentang revitalisasi pasar tradisional sehingga tujuan revitalisasi pasar dapat tercapai secara optimal.

4. Pemerintah Daerah Kabupaten Sumenep perlu melakukan monitoring dan evaluasi program revitalisasi.

\section{DAFTAR PUSTAKA}

Adisasmita, Rahardjo. (2011). Manajemen Pemerintahan Daerah. Yogyakarta : Graha Ilmu.

Adisasmita, Rahardjo. (2013). Teori-teori Pembangunan Ekonomi. Yogyakarta : Graha Ilmu.

Alfianita, Ella. (2015). Revitalisasi Pasar Dalam Prespektif Good Governance. Jurnal Administrasi Publik Vol.3 No.5 (2015). Diakses dari http:// download.portalgaruda.org.

Effendy, Sachlan. (2016). Administrasi Pemerintah Daerah. Surabaya: PMN \& UNIJA Press.

Hendrikus. (2007). Reorientasi Peran Pemerintah Dalam Pembangunan Ekonomi Di Tengah Arus Kekuatan Modal. Jurnal STIA LAN Bandung. 
Diakses

http://samarinda.lan.go.id.

Ibrahim, Adam. (2011). Revitalisasi Administrasi Pembangunan. Bandung : Alfabeta.

Kuncoro, Mudrajat. (2004). Otonomi \& Pembangunan Daerah. Jakarta : Erlangga.

Mensukseskan Program Revitalisasi Pasar Tradisional. Diakses pada 20 Oktober 2017 dari http:/ / ppresidenri.go.id.

Mitra. (2015). Peran Pemerintah Kabupaten Malang Dalam Meningkatkan Pembangunan Ekonomi Daerah Melalui Sektor Pariwisata. Jurnal Kebijakan dan Manajemen Publik Vol.1 No.3 (2015). Diakses dari www.academia.edu.

Mujiatun. (2014). Peran Pemerintah Tentang Pengembangan Perekonomian Dalam Prespektif Sistem Ekonomi Kapitalis, Sosialis dan Islam. Jurnal Ekonomi Vol. 3 No. 1 (2014). Diakses dari http://jurnal.uinsu.ac.id.

Nurman. (2015). Strategi Membangun Daerah. Jakarta : PT. Grafindo Persada

Pasar Anom Baru Masih Semrawut, Komisi II Segera Panggil Disperindag. 2017. Diakses pada 7 April 2017 dari www.koranmadura.com.

Pasar Anom Blok A Pasar Anom Baru Banyak Tak Laku. (2017). Diakses pada 7 September 2017 dari www.koranmadura.com.

Peraturan Mentri Dalam Negeri Republik Indonesia Nomor 20 Tahun 2012 Tentang Pengelolaan dan Pemberdayaan Pasar Tradisional.

Program Kerja 99 Hari, Bupati dan Wakil Bupati Sumenep Terpilih. Diakses pada 7 April 2017 dari http://newsmadura.com.
Revitalisasi Dengan Penerapan Pasar Pintar Pada Pasar Tradisional. Diakses Pada 10 Oktober 2017 dari http://library.binus.ac.id.

Revitalisasi Pasar Tradisional Di Sumenep Belum Maksimal. Diakses Pada 26 Nopember 2017 dari http://seputarmadura.com.

Said, Muhammad. 2015. Teori dan Isu Pembangunan. Surabaya: PMN \& UNIJA Press.

Sanusi, Bachrawi. (2000). Pengantar Perencanaan Pembangunan. Jakarta :

Fakultas Ekonomi Universitas Indonesia.

Sjafrizal. (2015). Perencanaan Pembangunan Daerah Dalam Era Otonomi. Jakarta: PT. Raja Grafindo Persada.

Sukirno, Sadono. (2010). Ekonomi

Pembangunan. Jakarta: Prenada

Media Group.

Soares, Armando. (2015). Peranan Pemerintah Daerah Dalam Perencanaan Pembangunan Daerah. Jurnal Ilmu sosial dan Ilmu Politik Vol. 4 No. 2 (2015). Diakses dari http://publikasi.umitri.ac.id.

Undang-undang Republik Indonesia

Nomor 7 Tahun 2014 tentang

Perdagangan.

Wiranta. (2015). Penguatan Peran Pemerintahan Daerah Dalam Mendorong Pertumbuhan Ekonomi Lokal. Jurnal Pusat Kajian Pendidikan dan Pelatihan Aparatur Vol. 2 No. 3 (2015). Diakses dari http://juliwi.com. 